\title{
ЕКОЛОГІЯ
}

УДК712.253 (477.63)

doi: 10.25128/2078-2357.21.1-2.6

Ю. С. ЮХИМЕНКО, Л. І. БОЙКО, Н. М. ДАНИЛЬЧУК, О. В. КРАСНОШТАН, О. П. КОРЖ

Криворізький ботанічний сад НАН України вул. Маршака, 50, Кривий Ріг, Дніпропетровська область, 50089

e-mail: yukhimenkoj@gmail.com

\section{СТАН ПРЕДСТАВНИКІВ РОДУ РОРULUS L. У ПАРКУ «САКСАГАНСЬКИЙ» МІСТА КРИВИЙ РІГ (ДНІПРОПЕТРОВСЬКА ОБЛАСТЬ)}

У парку «Саксаганський» міста Кривий Ріг досліджено стан представників роду Populus, частка яких становить 14,6 \% від загальної кількості дерев та $21 \%$ від загальної кількості таксонів. Переважна кількість екземплярів знаходиться у віці близько 40 років, які в умовах Криворіжжя потребують постійного догляду. Загальний стан рослин роду Populus можна вважати ослабленим, що може бути пов'язане 3 відсутністю відповідного догляду за деревами. Найкращий життєвий стан мають насадження Populus simonii, найгірший - P. berolinensis. Доцільною при визначенні доглядних робіт $є$ попередня експертна оцінка щодо особливості експлуатації представників цього роду, зокрема визначення типу оптимального обрізування та вікових меж для повного видалення рослин. Рекомендовано збагатити насадження парку новими посадками P. bolleana, які мають високі естетичні властивості, а також впровадити представників цього роду, зокрема P. suaveolens Fisch. ex Loudon, P. balsamifera L. тощо.

Ключові слова: Кривий Ріг, парк «Саксаганський», Рориlиs, життєвий стан, радикальне обрізування.

Місто вважається найяскравішим прикладом порушення природних екосистем, у якому через нестачу продуцентів та редуцентів колообіг речовин перетворюється на пряму смугу. Через це підтримання міського середовища потребує постійного внесення людиною додаткової енергії [16]. У цих умовах особливої уваги потребують зелені насадження, зокрема парки великих промислових міст.

Кривий Ріг розташований у степу і характеризується поєднанням доволі складних природних умов існування та значного антропогенного навантаження у вигляді важкої промисловості та автотранспорту.

Вважається, що в умовах індустріальних центрів представники роду Populus L. мають достатньо високу стійкість до техногенного забруднення $[9,19]$. Широкий внутрішньовидовий поліморфізм, екологічна пластичність та здатність до вегетативного розмноження зробили їх перспективними для інтродукції та культивування на південному сході України.

Невибагливих до умов зростання, зі швидким темпом росту, представників роду Populus останні 50 років використовують в озелененні населених пунктів степової зони України. Проте, через швидкий ріст значна частка дерев досягла максимального віку зрілості, частина їх випала 3 насаджень, а інші перебувають у незадовільному або навіть аварійному стані. Як наслідок, рослини практично перестали виконувати захисні і декоративні функції $[4,13,18]$. 
Одним із засобів догляду за деревами є обрізування крони, основною метою якого $є$ омолодження та надання декоративності рослинам [5]. Проте, працівники міських служб комунального господарства часто при обрізуванні дерев не дотримуються строків його проведення та технології виконання зрізів, не враховуючи біологічні особливості виду [10]. Останнім часом у містах, замість санітарної обрізки, здійснюють радикальне обрізування крон дерев, яке передбачає повне видалення крони і верхньої частини стовбура дерева. Це $\epsilon$ найбільш травматичним і малоестетичним способом, який в усьому світі вважається варварським [6]. Видалення крони в дерев суттєво зменшує їхні середовищетвірну i декоративну функції. До того ж, радикальне обрізування крони в дорослих дерев згубно позначається на їхньому життєвому стані, призводить до передчасного старіння і загибелі насаджень [2].

У деяких наукових публікаціях наведено результати аналізу впливу неправильного обрізування дерев на стан рослин та виконання ними екологічних функцій. Автори вказують на ослаблення рослин, підвищення вразливості до хвороб, шкідників та збільшення захворюваності, на морфологічні та анатомічні зміни листків, порушення ростових процесів, зниження пилозатримуючої функції, збільшення чутливості листків до атмосферного забруднення тощо [3, 17].

Згідно «Правил утримання зелених насаджень у населених пунктах України» [14], тривалість експлуатації дерев із швидким темпом росту, до яких належать і види роду Populus, становить 70 років у парках та скверах і 45 років у вуличних насадженнях. При цьому, рослини в межах одного парку можуть зростати в різних екологічних умовах, оскільки частина насаджень контактує 3 прилеглими вулицями. Тому виникає питання, наскільки універсальними можуть бути строки та способи експлуатації дерев.

Попередніми дослідженнями встановлено, що в парках Кривого Рогу зростає 8 видів та один гібрид роду Populus, які займають 27,3 \% загальної площі 22 парків міста. Найбільш поширеними є три види: Populus nigra L., P. bolleana Lauche $i$ P. italica (Münchh.) Moench, частка яких становить $61 \%$ від усіх представників цього роду [7].

Метою нашої роботи було визначення стану представників роду Populus в умовах парку «Саксаганський» та визначення особливостей їхньої подальшої експлуатації.

\section{Матеріал і методи досліджень}

Дослідження проводились у 2010, 2015 та 2020 роках на території парку «Саксаганський» м. Кривий Ріг. Парк займає площу $5600 \mathrm{~m}^{2}$. Дерева представлені різними віковими групами, проте вік окремих екземплярів не перевищує сорока років. У 2015 році було проведено радикальне обрізування переважної більшості деревних рослин з метою усунення аварійності та покращення санітарного стану. Радикальне обрізування можна поділити на наступні типи: слабкий (залишаються скелетні гілки другого та третього галуження), середній (залишаються скелетні гілки першого галуження) та сильний (залишається лише стовбур).

При обстеженні зелених насаджень висоту дерев заміряно за допомогою висотоміра Макарова, діаметр стовбура визначено мірною вилкою. Життєвий стан досліджуваних дерев визнали за модифікованою шкалою Л. С. Савельєвої [8], де «відмінний» стан дерева - габітус повністю збережений, відсутні помітні пошкодження крони та стовбура (7-8 балів), «добрий» стан - близький до попереднього, але менш облиствлений (5-6 балів), «задовільний» переважна частина скелетних гілок жива (3-4 бали), «незадовільний» - жива менша частина скелетних гілок дерева (1-2 бали), «сухе» дерево - повністю відмерле (0 балів). Оцінку життєвого стану деревостанів визначали за модифікованою формулою В. А. Алесєєва [1], оцінку стану окремого дерева - за шкалою:

$$
\mathrm{L}_{\mathrm{n}}=\frac{100 n_{1}+70 n_{2}+40 n_{3}+5 n_{4}}{N} \text {, де }
$$

$\mathrm{L}_{\mathrm{n}}$ - відносний життєвий стан деревостану;

$\mathrm{n}_{1}-$ кількість здорових дерев (7-8 балів);

$\mathrm{n}_{2}$ - кількість ослаблених дерев (5-6 балів);

$\mathrm{n}_{3}$ - кількість сильно ослаблених дерев (3-4 балів);

ISSN 2078-2357. Наук. зап. Терноп. нац. пед. ун-ту. Сер. Біол., 2021, Т. 81, № 1-2 
$\mathrm{n}_{4}$ - кількість відмираючих дерев (1-2 бали);

$\mathrm{N}$ - загальна кількість дерев.

При показнику Ln 100-80 життєвий стан деревостану оцінюється як «здоровий», при 7950 деревостан вважається пошкодженим (сильноослабленим), при 19 і нижче - повністю зруйнованим.

Математична обробка результатів здійснювалася за Г. Ф. Лакіним [12].

\section{Результати досліджень та їх обговорення}

Нині загальна кількість дерев у парку становить 487 екземплярів, із яких 18 повністю відмерлі (життєздатність 0 балів) та підлягають видаленню. Частка представників роду Populus становить 14,6 \% (71 екземпляр) від загальної кількості дерев та $21 \%$ від загальної кількості таксонів. У 2010 році середня висота всіх видів цього роду в парку становила 18-24 м, а життєвий стан складав 7-8 балів. У 2015 році було проведено радикальне обрізування сильного типу майже всіх рослин роду Populus, що зростають у парку, на висоті близько 7-8 м. На даний час висота таких рослин становить в середньому 10-15 м. Таким чином, відростання за 5 років сягнуло 3-5 м. Життєвий стан більше половини рослин роду Populus дорівнює 6 балам, близько $30 \%$ - 7 балам та $15 \%$ - 8 балам. Два екземпляри (по одному екземпляру P. deltoides Marshal та $P . \times$ berolinensis K. Koch.) повністю відмерли (0 балів) внаслідок такого обрізування.

Низький рівень життєвого стану більшості рослин роду Populus свідчить про малу ефективність застосованого методу обрізування. Це може бути пов'язано з відсутністю експертної оцінки щодо стану і подальшої експлуатації дерев, а також строків проведення обрізування. Більшість дерев не потребувало радикального обрізування сильного типу, коли залишається лише стовбур. Для них було б достатньо застосувати середній або слабкий тип обрізування, що дало б можливість уникнути сильного травматичного ефекту в рослин.

Видовий склад представників роду Populus та чисельність кожного виду представлено в таблиці 1. Найбільш чисельним виявився P.deltoides - всього в парку зростає 26 екземплярів цього виду (37,7 \% від загальної кількості рослин цього роду), які належать до двох вікових груп. Морфометричні показники дерев цих груп не мають достовірних відмінностей, що може бути пов'язане з їхнім радикальним обрізуванням. Зменшення варіювання ширини стовбура 3 віком може пояснюватися більш активним ростом в товщину в цьому віці.

Таблиия 1

Морфометричні показники та життєздатність рослин роду Populus у парку «Саксаганський»

\begin{tabular}{|c|c|c|c|c|c|c|c|}
\hline \multirow{2}{*}{ Вид } & \multirow{2}{*}{$\mathrm{n}$} & \multirow{2}{*}{ Вік, роки } & \multicolumn{2}{|c|}{ Висота, м } & \multicolumn{2}{|c|}{ Діаметр стовбура, см } & \multirow{2}{*}{$\begin{array}{l}\text { Життєвий } \\
\text { стан, бали }\end{array}$} \\
\hline & & & $\mathrm{M} \pm \mathrm{m}$ & $\mathrm{Cv}, \%$ & $\mathrm{M} \pm \mathrm{m}$ & $\mathrm{Cv}, \%$ & \\
\hline \multirow{2}{*}{ Populus deltoides } & 10 & $20-29$ & $12,0 \pm 1,08$ & 28,3 & $39,6 \pm 4,14$ & 33,0 & $6-7$ \\
\hline & 16 & $30-39$ & $10,8 \pm 0,80$ & 29,9 & $44,9 \pm 2,25$ & 20,1 & $6-8$ \\
\hline $\begin{array}{c}\text { Populus } \times \\
\text { berolinensis }\end{array}$ & 13 & 3 & 0,58 & 11,59 & $\pm 2,67$ & 18,38 & 6 \\
\hline Populus simonii & 11 & $30-39$ & $12,4 \pm 0,85$ & 22,86 & $37,5 \pm 1,90$ & 16,86 & $7-8$ \\
\hline Populus italica & 8 & $30-40$ & $15,5 \pm 1,19$ & 21,77 & $59,0 \pm 3,09$ & 14,83 & $6-7$ \\
\hline Populus bolleana & 4 & $20-29$ & $15,0 \pm 1,25$ & 16,67 & $38,5 \pm 2,88$ & 14,93 & $6-8$ \\
\hline
\end{tabular}

Populus $\times$ berolinensis представлений 13 особинами, що становить майже $21 \%$ від загальної кількості рослин даного роду. Ці дерева зростають у віддаленій частині парку, тому не всі особини підпали радикальному обрізуванню. Висота некронованих особин за 10 років суттєво не змінилася внаслідок всихання верхніх гілок, проте життєвий стан значно погіршився й на сьогодні не перевищує 6 балів.

Populus simonii Carrière складає 17,7 \% від загальної чисельності рослин даного роду в парку i характеризується найкращим життєвим станом. Слід відзначити, що показники товщини стовбура в цього виду виявилися найменшими серед усіх досліджених видів. Populus italica має найбільшу висоту після радикального обрізування та найбільшу товщину стовбура. Незважаючи на це, життєвий стан поступається іншим видам. 
Populus bolleana має найменшу чисельність i представлений наймолодшими екземплярами. Ці рослини також не підпадали радикальному обрізуванню, у них видалені лише нижні гілки, що не усунуло всього сушняку в кроні і не підвищило життєвий стан окремих особин.

Було зареєстровано два екземпляри роду Populus 3 життєвим станом 0 балів. Оскільки в обох екземплярів при радикальній обрізці був залишений лише стовбур, можна передбачити, що це стало одним із факторів їх загибелі. Слід зазначити, що вік 30-40 років є доволі критичним, оскільки дерева всіх видів Populus у посушливих умовах степової зони переходять до стадії багатовікових генеративних рослин $\left(\mathrm{g}_{3}\right)$, коли відбувається спрощення життєвої форми, а саме різке зниження частки генеративних пагонів, ослаблення процесів росту i формування в пагонів та кореневої системи, переважання процесів відмирання над процесами новоутворення [20].

Було визначено відносний життєвий стан деревостанів Populus в парку. Встановлено, що здоровими можна вважати насадження $P$. deltoides $\left(\mathrm{L}_{\mathrm{n}}=82,0\right)$ та $P$. simonii $\left(\mathrm{L}_{\mathrm{n}}=100,0\right)$. Інші види знаходяться в ослабленому стані: P. bolleana $\mathrm{L}_{\mathrm{n}}=77,5 ;$ P. italica $\mathrm{L}_{\mathrm{n}}=73,8 ;$; . berolinensis $\mathrm{L}_{\mathrm{n}}=65,4$. Загальний стан рослин роду Populus можна вважати ослабленим $\left(\mathrm{L}_{\mathrm{n}}=74,4\right)$, що може бути пов'язане, по-перше, 3 порушенням правил обрізування, по-друге, 3 надмірним урботехногенним навантаженням промислового міста, по-третє, 3 прискоренним старінням деревних рослин у посушливих умовах степової зони.

Також у парку наявні сім екземплярів молодих рослин роду Populus (табл. 2), 3 яких більшість належить до $P . \times$ berolinensis. Оскільки ростові процеси та життєвий стан мають високі показники, то можна говорити про високі адаптаційні властивості у молодому віці рослин роду Populus в умовах даного парку.

Таблиия 2

Морфометричні показники та життєздатність молодих рослин роду Populus у парку «Саксаганьский»

\begin{tabular}{|c|c|c|c|c|c|}
\hline Вид & $\mathrm{n}$ & Вік, роки & Висота, м & Діаметр стовбура, см & Життевий стан \\
\hline $\begin{array}{c}\text { Populus } \\
\text { deltoides }\end{array}$ & 2 & $10-12$ & 9 & $11-14$ & 8 \\
\hline $\begin{array}{c}\text { Populus } \\
\text { berolinensis }\end{array}$ & 4 & $5-7$ & $4-8$ & $6-14$ & 8 \\
\hline $\begin{array}{c}\text { Populus } \\
\text { simonii }\end{array}$ & 1 & 6 & 5 & 13 & 8 \\
\hline
\end{tabular}

Таким чином, представники роду Populus в парку «Саксаганський» Кривого Рогу в більшості віднесені до категорії ослаблених. Найкраще зростають молоді екземпляри, у дорослому віці добрий життєвий стан має Populus simonii. Радикальне обрізування сильного типу є стресовим для всіх видів цього роду. Значно доцільнішим було б залишення скелетних гілок першого, другого або навіть третього галуження в залежності від стану рослин. В окремих випадках достатнім було б застосування лише санітарного або формуючого обрізування, що підтримувало би кращими функціонування та декоративність рослин.

Щодо часу експлуатації представників роду Populus, то його визначення повинно здійснюватися індивідуально не лише в межах міста, але й в межах окремих насаджень. Також слід відмовитись від узагальненого підходу з догляду дерев. Доречно залучати фахівців для визначення стану окремих дерев та найбільш ефективних методів їхнього догляду. Терміни санітарного та, тим більше, радикального обрізування слід обмежити весняним періодом до початку сокоруху в рослин.

На наш погляд, насадження парку потребують додаткового висаджування молодих екземплярів роду Populus, особливо P. bolleana, як одного з найбільш декоративних видів. Також рекомендовано створити посадки різного типу (алея, група, солітер) з нових для парку видів та культиварів Populus, зокрема P. suaveolens Fisch. ex Loudon, P. balsamifera L., P. wettsteinii Hämet-Ahti, P. trichocarpa Torr. \& A.Gray ex Hook., P. simonii Carr. 'Piramidalis' та 
ін. Дерева 3 низьким рівнем життєвого стану повинні видалятися незалежно від віку й замінюватися молодими екземплярами, оскільки знижують декоративність насаджень та, вірогідно, уражені шкідниками або хворобами. Наявні насадження потребують постійного моніторингу їхнього стану та відповідного догляду. У подальшому передбачається здійснення експертних оцінок стану рослин роду Populus та надання рекомендацій щодо робіт з догляду за насадженнями парку.

\section{Висновки}

Представники роду Populus в парку «Саксаганський» Кривого Рогу становлять 14,6 \% від загальної кількості дерев. Переважна кількість екземплярів знаходиться у віці близько 40 років, які в умовах Криворіжжя потребують систематичного санітарного обрізування, а періодично радикального обрізування.

До більшості рослин роду Populus у парку було застосовано радикальне обрізування крони сильного типу у 2015 році. Внаслідок отриманого стресу після застосованих робіт 3 догляду життєвий стан більшості рослин цього роду знижений, 2 екземпляри загинули. Найкращий життєвий стан мають насадження Populus simonii, найгірший - P. berolinensis.

Доцільною при визначенні доглядних робіт є попередня експертиза щодо особливості експлуатації представників роду Populus, зокрема визначення типу радикального обрізування та вікових меж для повного видалення рослин.

Рекомендовано збагатити насадження парку новими посадками P. bolleana, які мають високі естетичні властивості, а також впровадити інших перспективних представників цього роду, зокрема $P$. suaveolens Fisch. ex Loudon, P. balsamifera L. тощо.

1. Алексеев В. А. Диагностика жизненного состояния деревьев и древостоев. Лесоведение, 1989. № 4. C. 51-57.

2. Бакулин Т. В. Использование тополя в озеленении промышленных городов Сибири. Сиб. эколог. журн. 2005. № 4. С. 563-571.

3. Бессонова В.П., Глубока В. М. Вплив омолоджувального обрізання на ураженість хворобами деревних рослин в умовах дії автомобільних викидів. Питання біоіндикації та екології. Запоріжжя. 2008. Вип. 13. № 2. С. 105-112.

4. Бессонова В. П., Пономарьова О. А., Іванченко О.Є. Видове різноманіття та життєвий стан деревних насаджень вздовж автотраси південного напрямку м. Дніпропетровськ. Питання біоіндикаиії та екологї̈, 2014. Вип. 19. № 2. С. 64-84.

5. Бриккел К. Обрезка деревьев. М. : Мир, 1992. 198 с.

6. Горышина Т. К. Растение в городе. Л. : Из-во ЛГУ, 1991. 152 с.

7. Данильчук Н. М., Федоровский В. Д., Коршиков И. И. Тополя в парках Кривого Рога. Інтродукиія рослин, 2015. № 4. С. 99-106.

8. Задорожная Д. В. Интегральная оценка жизнеспособности Platanus $\times$ acerifolia (AITON) Willd. в городских насаждениях. Промышленная ботаника, 2013. Вып. 13. С. 136-142.

9. Кулагин А. А., Шагиева Ю. А. Древесные растения и биологическая консервация промышленных загрязнителей. М. : Наука, 2005. 190 с.

10. Курницька М. П., Пахолюк О. Т. Аналіз реакції деревних рослин на сильне кронування. Наук. вісник НЛТУ України: зб. наук.-техн. праць. Львів : РВВ НЛТУ України, 2012. Вип. 22.5. С. 30-33.

11. Кучерявий В. П., Дудин Р. Б. Особливості обрізування деревно-чагарникових рослин. Методичні вказівки. Львів : УкрДЛТУ, 2003. 60 с.

12. Лакин Г. Ф. Биометрия. М. : Высшая школа, 1990. 352 с.

13. Левон Ф. М. Зелені насадження в антропогенно трансформованому середовищі. К. : ННЦІАЕ, 2008. $364 \mathrm{c}$.

14. Наказ № 105, Міністерство будівництва, архітектури та житлово-комунального господарства України від 10.04.2006 «Про затвердження Правил утримання зелених насаджень у населених пунктах України».

15. Семенюта Ф. И. Лесная таксация. М.-Л. : Гослесбумиздат, 1961. 340 с.

16. Социально-экономический потенциал устойчивого развития: учебник / под ред.: Л. Г. Мельника, Л. Хенса. 2-е изд., стер. Сумы : Университетская книга, 2009. 1120 с. 
17. Суслова Е. П. Populus bolleana Lanche в насаждениях промышленных городов юго-востока Украины. Scientific Journal of Klaipeda State College «Formation of urbangreen areas», 2017. 1 (14) P. 225-231.

18. Суслова О. П., Поляков О. К., Нецветов М. В. Життєздатність деревних рослин у міських вуличних насадженнях на південному сході України. Пром. Ботаника, 2012. Вып. 12. С. 12-18.

19. Уразгильдин Р. В., Кужлева Н. Г. Анатомо-морфологическая характеристика листьев Populus в условиях промышленного загрязнения в Предуралье. Биоразнообразие и ресурсы Урала и сопредельных территорий. Материалы Междунар. конф. Оренбург : ИПК «Газпромпечать, 2001. C. 179-181.

\section{References}

1. Alekseev V. A. Diagnostika zhiznennogo sostojanija derev'ev i drevostoev. Lesovedenie, 1989. № 4. S. 5157. [in Russian]

2. Bakulin T. V. Ispol'zovanie topolja v ozelenenii promyshlennyh gorodov Sibiri. Sib. jekolog. zhurn. 2005. № 4. S. 563-571. [in Russian]

3. Bessonova V.P., Hluboka V. M. Vplyv omolodzhuvalnoho obrizannia na urazhenist khvorobamy derevnykh roslyn v umovakh dii avtomobilnykh vykydiv. Pytannia bioindykatsii ta ekolohii. Zaporizhzhia. 2008. Vyp. 13. № 2. S. 105-112. [in Ukrainian]

4. Bessonova V. P., Ponomarova O. A., Ivanchenko O. Ye. Vydove riznomanittia ta zhyttievyi stan derevnykh nasadzhen vzdovzh avtotrasy pivdennoho napriamku m. Dnipropetrovsk. Pytannia bioindykatsii ta ekolohii, 2014. Vyp. 19. № 2. S. 64-84. [in Ukrainian]

5. Brikkel K. Obrezka derev'ev. M. : Mir, 1992. 198 s. [in Russian]

6. Goryshina T. K. Rastenie v gorode. L. : Iz-vo LGU, 1991. 152 s. [in Russian]

7. Danylchuk N. M., Fedorovskyi V. D., Korshykov Y. Y. Topolia v parkakh Kryvoho Roha. Introduktsiia roslyn, 2015. № 4. S. 99-106. [in Russian]

8. Zadorozhnaja D. V. Integral'naja ocenka zhiznesposobnosti Platanus $\times$ acerifolia (AITON) Willd. v gorodskih nasazhdenijah. Promyshlennaja botanika, 2013. Vyp. 13. S. 136-142. [in Russian]

9. Kulagin A. A., Shagieva Ju.A. Drevesnye rastenija i biologicheskaja konservacija promyshlennyh zagrjaznitelej. M. : Nauka, 2005. 190 s. [in Russian]

10. Kurnytska M. P., Pakholiuk O. T. Analiz reaktsii derevnykh roslyn na sylne kronuvannia. Nauk. visnyk NLTU Ukrainy: zb. nauk.-tekhn. prats. Lviv: RVV NLTU Ukrainy, 2012. Vyp. 22.5. S. 30-33. [in Ukrainian]

11. Kucheriavyi V. P., Dudyn R. B. Osoblyvosti obrizuvannia derevno-chaharnykovykh roslyn. Metodychni vkazivky. Lviv : UkrDLTU, 2003. 60 s. [in Ukrainian]

12. Lakin G. F. Biometrija. M. : Vysshaja shkola, 1990. 352 s. [in Russian]

13. Levon F. M. Zeleni nasadzhennia v antropohenno transformovanomu seredovyshchi. K. : NNTsIAE, 2008. 364 s. [in Ukrainian]

14. Nakaz № 105, Ministerstvo budivnytstva, arkhitektury ta zhytlovo-komunalnoho hospodarstva Ukrainy vid 10.04.2006 «Pro zatverdzhennia Pravyl utrymannia zelenykh nasadzhen u naselenykh punktakh Ukrainy». [in Ukrainian]

15. Semenjuta F. I. Lesnaja taksacija. M.-L. : Goslesbumizdat, 1961. 340 s. [in Russian]

16. Social'no-jekonomicheskij potencial ustojchivogo razvitija: uchebnik / pod red.: L. G. Mel'nika, L. Hensa. 2-e izd., ster. Sumy : Universitetskaja kniga, 2009. 1120 s. [in Russian]

17. Suslova E. P. Populus bolleana Lanche v nasazhdenijah promyshlennyh gorodov jugo-vostoka Ukrainy. Scientific Journal of Klaipeda State College «Formation of urbangreen areas», 2017. 1(14) P. $225-231$. [in Russian]

18. Suslova O.P., Poljakov O. K., Necvetov M. V. Zhitt€zdatnist' derevnih roslin u mis'kih vulichnih nasadzhennjah na pivdennomu shodi Ukraïni. Prom. Botanika, 2012. Vyp. 12. S. 12-18. [in Ukrainian]

19. Urazgil'din R. V., Kuzhleva N. G. Anatomo-morfologicheskaja harakteristika list'ev Populus v uslovijah promyshlennogo zagrjaznenija v Predural'e. Bioraznoobrazie i resursy Urala i sopredel'nyh territorij. Materialy Mezhdunar. konf. Orenburg: IPK «Gazprompechat», 2001. S. 179-181. [in Russian] 
Y. S. Yukhimenko, L. I. Boyko, N. M. Danilchuk, O. V. Krasnoshtan, O. P. Korzh

Kryvyi Rih Botanical Garden, National Academy of Sciences of Ukraine, Ukraine

STATE REPRESENTATIVES OF POPULUS L. IN PARK «SAKSAGANSKYI» IN KRYVYI RIH CITY (DNIPROPETROVSK REGION)

We studied the state of poplars in the park Saksaganskyi in Kryvyi Rih, their share being $14.6 \%$ of the total number of trees and $21 \%$ of the total number of taxa. The vast majority of specimens are aged 40; such trees in the conditions of Kryvyi Rih need constant care. The general condition of poplars can be considered weakened, it may be due to the lack of proper care. Plantations of Populus simonii are of the best state, while those of $P$. berolinensis are of the worst state. Preliminary expert assessment of the peculiarities of poplar operation, in particular the determination of the optimal pruning type and age limits for complete removal of plants, is appropriate to determine maintenance works. It is recommended to enrich the park plantings with new plantings of $P$. bolleana, which have high aesthetic properties, as well as to introduce species of this genus, in particular $P$. suaveolens Fisch. ex Loudon, P. balsamifera L. et al.

Keywords: Kryvyi Rih, park Saksaganskyi, Populus, vital state, radical pruning.

Надійшла 03.02.2021. 